
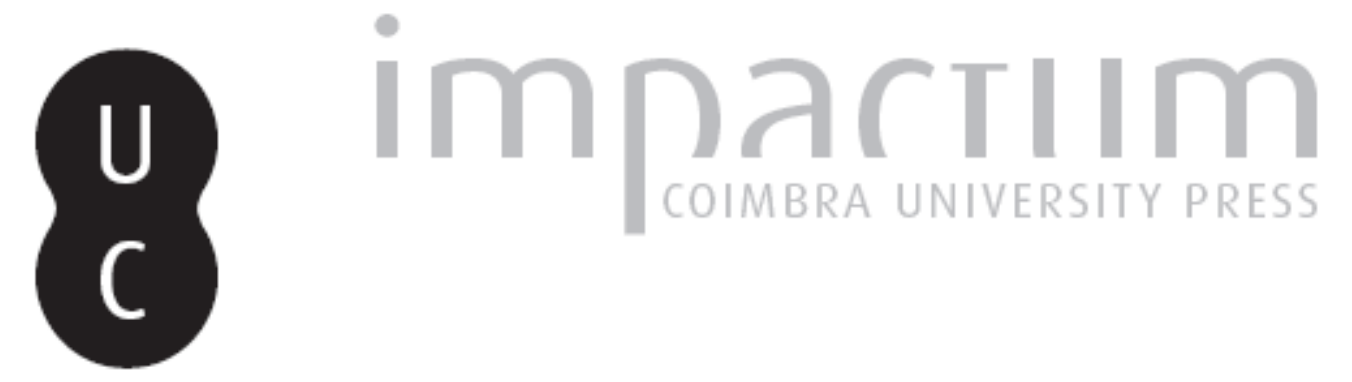

\title{
A escrita filosófica e o drama do conhecimento em Platão
}

Autor(es): Costa, Gilmário Guerreiro da

Publicado por: Annablume Clássica

URL persistente:

URI:http://hdl.handle.net/10316.2/24514

DOI:

DOI:http://dx.doi.org/10.14195/1984-249X_11_3

Accessed : $\quad$ 26-Apr-2023 14:54:37

A navegação consulta e descarregamento dos títulos inseridos nas Bibliotecas Digitais UC Digitalis, UC Pombalina e UC Impactum, pressupõem a aceitação plena e sem reservas dos Termos e Condições de Uso destas Bibliotecas Digitais, disponíveis em https://digitalis.uc.pt/pt-pt/termos.

Conforme exposto nos referidos Termos e Condições de Uso, o descarregamento de títulos de acesso restrito requer uma licença válida de autorização devendo o utilizador aceder ao(s) documento(s) a partir de um endereço de IP da instituição detentora da supramencionada licença.

Ao utilizador é apenas permitido o descarregamento para uso pessoal, pelo que o emprego do(s) título(s) descarregado(s) para outro fim, designadamente comercial, carece de autorização do respetivo autor ou editor da obra.

Na medida em que todas as obras da UC Digitalis se encontram protegidas pelo Código do Direito de Autor e Direitos Conexos e demais legislação aplicável, toda a cópia, parcial ou total, deste documento, nos casos em que é legalmente admitida, deverá conter ou fazer-se acompanhar por este aviso.

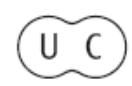



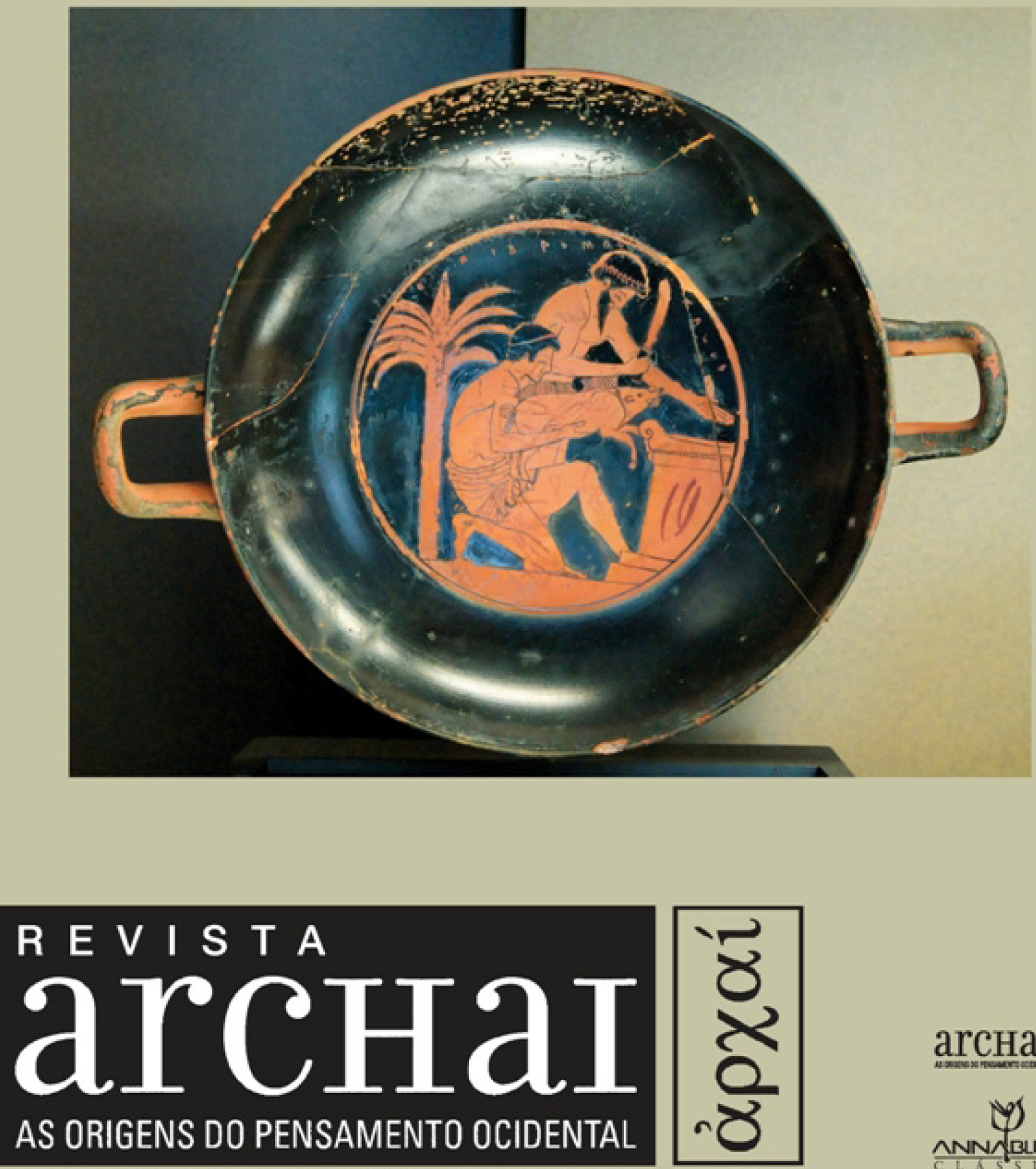

ARCHAI JOURNAL: ON THE ORIGINS OF WESTERN THOUGHT

arcHaI凰

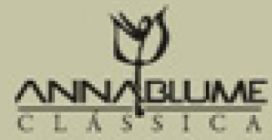




\section{A ESCRITA FILOSÓFICA E 0 DRAMA DO CONHECIMENTO EM PLATÃO}

COSTA, G. G. da (2013). A escrita filosófica e o drama do conhecimento em Platão. Archai, n. 11, jul-dez, p. 33-46.

RESUMO: Aos estudos em filosofia antiga deparam-se algumas dificuldades na articulação entre a crítica de Platão à escrita e o cuidado que ele concedia precisamente aos seus textos escritos. Tais desafios intensificam-se quando se concede ênfase aos traços cênicos na apresentação das ideias e da Ideia nos diálogos platônicos. Se não chega a ser um paradoxo, dimensionam-se tensões e impasses nesse percurso. Examinamos neste ensaio um caminho explicativo possivel: a de que o filósofo grego teria elaborado um grande drama (Drama) do conhecimento, que marcaria por vias diversas o percurso da escrita filosófica ao longo da sua história, num enredamento fino de forma e conteúdo, ele mesmo matriz de uma resposta teórica e crítica no âmbito do conhecimento.

PALAVRAS-CHAVE: Escrita; Drama; Platão; Diálogos; Conhecimento.

ABSTRACT: Studies in ancient philosophy faced some difficulties in articulating Plato's critique of writing and the care he granted precisely to his written texts. These challenges are intensified when it is given emphasis on the scenic features in the presentation of ideas and the Idea in the Platonic dialogues. If this is not exactly a paradox, it would reveal some tensions and deadlocks. We examine in this essay a possible explanatory way: that the Greek philosopher would have drawn a great drama of knowledge which would mark the route of philosophical writing throughout its history in a fine enmeshment of form and content, itself a theoretical and critic response within knowledge.

KEYWORDS: Writing; Drama; Plato, Dialogues; Knowledge.
* Professor da Universidade Católica de Brasília. Pós-doutorando das Universidades de Brasília e de Coimbra,gilmario@ ucb.br.

Para Ester e Luiz Cláudio
Gilmário Guerreiro da Costa*

1. Por sorte de notável ironia, não raras as tentativas de defender Platão das acusações de dogmatismo servem-se da afirmação do caráter ambíguo e rico da sua escrita. Seria precisamente o traço repudiado em Fedro 275a aquele dotado de maior força e convencimento. Noutros termos, o filósofo ressurge no reencontro com o artista. Em grande medida, as razões desse fenômeno residem em que nos diálogos de Platão lemos 0 grande drama do conhecimento e da pesquisa. Um grande feito da cultura grega. 0 presente ensaio intenta examinar algumas possibilidades explicativas e compreensivas desse fenômeno no texto platônico, focalizando três instâncias intimamente relacionadas entre si: a peculiaridade da sua escrita, seu caráter artístico e o gesto crítico e ambíguo com que instaura sua relação temática e formal com a tragédia.

A escrita dos diálogos movimenta cena textual em que se desdobram, com feição peculiar, os mais variados problemas da filosofia. Semelhante procedimento exibe o caráter inquietante da trajetória do pensamento em busca da verdade que, independentemente do maior ou menor sucesso dos diversos ensaios, finda por modificá-lo indelevelmente. As marcas deixadas resultam de um profundo zelo pedagógico, sob a efígie do grande mestre, Sócrates, e 
também dos expedientes construídos com arte rara na tessitura dos diálogos.

A escrita reencontra-se, nessa provocação, com o seu outro - o leitor, cujo agir é ambíguo, num misto de interpretação e interpelação. Lê o texto, à distância, mas também participa do jogo textual a ele reagindo e the conferindo sentido. É assim no movimento e temporalidade da escrita que se propugna pela aproximação da eternidade das Ideias. 0 paradoxo talvez seja aparente - o que não esmaece o quadro dramático desse projeto.

2. A reflexão platônica, seja por sua configuração textual, seja pelos temas que enfrenta, revela-se especialmente sugestiva para um diálogo entre filosofia e literatura. Para o dizermos em cifra hermenêutica, o Platão escritor amiúde remaneja os dados dessa "aproximação na distância", movendo no proscênio algumas questões que se tornariam obsessivamente retomadas ao longo da história da filosofia.

Nos intercursos entre filosofia e literatura, há de se precaver contra algumas ciladas metodológicas, em especial a presunção de se extrair da obra literária verdades filosóficas mais gerais, como se o texto literário nada mais fosse que ilustração dessas ideias. Em gesto raríssimo de lucidez e humildade, Benedito Nunes confessa ter incorrido em semelhante equívoco quando escreveu seu primeiro estudo sobre Clarice Lispector:

Assim, nesse primeiro estudo, intitulado 0 mundo de Clarice Lispector, apresentei a ficção da romancista de $A$ paixão segundo G.H. como uma ilustração do pensamento sartriano. Eis o parco rendimento - ou rendimento nulo? - da Crítica desenvolvida como paráfrase filosófica. (NUNES, 1993, p. 197-8)

Dos procedimentos mais especificamente literários que o autor afirma ter esquecido nesse estudo, destacam-se a construção dos personagens, características da sua linguagem, e as relações entre história e discurso. Servindo-se do exemplo de Walter Benjamin, o autor (NUNES, 1993, p. 198) diz que o único modo de fazer justiça às exigências filosóficas de verdade no que tange às relações entre filosofia e literatura, seria concedendo a necessária atenção à verdade da obra como ficção, como literatura.

0 diálogo exigido pela relação entre filosofia e literatura faria da hermenêutica, segundo B. Nunes, um exercício metódico capaz de contornar diversos equívocos e mesmo arbitrariedades. Nesse contexto, destaca duas falácias recorrentes em diversas abordagens desse exercício comparativo:

1. A visada no texto literário como simples ilustração de uma verdade filosófica mais geral (NUNES, 1993, p. 198).

2. A possibilidade de esgotamento científico da obra literária (NUNES, 1993, p. 198)

Sublinharemos, um pouco mais adiante, o quanto 0 assesto da inesgotabilidade do texto literário também alcança a escrita platônica. Trata-se da condição para se fazer justiça ao filósofo grego: colocá-lo ao abrigo de acusações extremadas de dogmatismo. Tal proposta responde coerentemente às diretrizes do próprio texto platônico - 0 diálogo enquanto efígie móvel da persistência filosófica na busca da verdade, em seu matiz dramático, incerto.

Em um artigo rico em sugestões e caminhos investigativos, Jeanne Marie Gagnebin detém-se na análise e interpretação do que chama de "as formas literárias da filosofia" (2006). 0 recorte, segundo the parece, tem a vantagem de resistir a um plano meramente normativo: “Tal recorte tem a vantagem de não colocar de antemão uma questão normativa sobre as diferenças, os direitos, os domínios respectivos dos discursos literários e filosóficos" (GAGNEBIN, 2006, p. 201). Ela julga necessário, enquanto ensaio preparatório, que se revisite o problema das relações entre forma e conteúdo. Há neste item notável substrato benjaminiano: "não só quais "conteúdos filosóficos" estão presentes ali, mas como são transformados em "conteúdos literários"." (GAGNEBIN, 2006, p. 201). Em momentos, as distinções entre forma e conteúdo evidenciam ineficácia dialética e procedimentos insuficientes para se pensar seja a filosofia, seja a literatura.

A caracterização do ofício do filósofo e do escritor quase sempre dissemina clichês variados, tais como a asserção de caber aos filósofos a respon- 
sabilidade por pensar, e aos escritores, a expressão escrita. No que tange especificamente à filosofia, esses estereótipos expressam certa desconfiança com a retórica. Toma-se a textualidade, em sentido amplo, apenas enquanto instrumento: “Até no próprio meio filosófico, por exemplo, na academia, reina certa desconfiança em relação aos aspectos formais mais apurados de uma palestra oral ou de um texto escrito de filosofia." (GAGNEBIN, 2006, p. 202)

No entanto, uma análise mais atenta da questão revela a insuficiência do encaminhamento dicotômico que emerge desses lugares comuns. Segundo Gagnebin, em afirmação percuciente, o pensamento não se elabora sem linguagem, "sem o tatear na temporalidade das palavras" (GAGNEBIN, 2006, p. 202). A linguagem é vazada em metáforas e retórica, e é dessa matéria heterogênea que a escrita filosófica lança mão, conscientemente ou não. Afim a essas considerações, segue a ênfase na interrelação entre forma, exposição e conhecimento. Entrelaçam-se internamente, de modo que a forma resiste a ser mero adereço.

Resulta emblemático, nesse contexto, o estudo da forma-diálogo em Platão. Ela explicaria os impasses e aparentes inconsistências da filosofia platônica. Nos diálogos, descerra-se o movimento complexo da própria vida. Procedendo a surpreendente mímesis, extrai na forma uma imagem móvel da realidade do existir humano, do conhecimento, ou melhor, do drama na busca desse conhecimento.

se levarmos a sério a forma diálogo, isto é, a renovação constante do contexto e dos interlocutores, o movimento de idas e vindas, de avanços e regressos, as resistências, o cansaço, os saltos, as aporias, os momentos de elevação, os de desânimo etc., então percebermos que aquilo que Platão nos transmite não é nenhum sistema apodítico, nenhuma verdade proposicional, mas, antes de mais nada, uma experiência: a do movimento incessante do pensar, através da linguagem racional (logos) e para além dela - "para além do conceito através do conceito", dirá também Adorno. (GAGNEBIN, 2006, p. 204)

A mímesis, pretensamente expulsa no âmbito da representação dos conteúdos da vida, imiscui- -se nas teias da própria constituição formal dos diálogos. Trata-se igualmente de uma experiência do pensar, na qual não apenas os interlocutores de Sócrates, mas também os seus leitores são convidados a participar.

3. No ensaio modelar que escreveu acerca das Afinidades eletivas, de Goethe, Walter Benjamin avança uma dupla contribuição que nos interessa. $A$ primeira liga-se ao estatuto das relações entre forma e conteúdo. Parecendo-lhe pecar por uma dicotomia excessiva, substitui os termos em questão pelos conceitos de teor de verdade (Wahrheitsgehalt) e teor coisal (Sachgehalt). Seu interesse reside em sublinhar a imiscibilidade desses elementos na obra de arte. Formula espécie de lei da escrita literária: “quanto mais significativo for o teor de verdade de uma obra, de maneira tanto mais inaparente e íntima estará ele ligado ao seu teor factual." (BENJAMIN, 2009, p. 12) Trata-se da afirmação da verdade da obra enquanto ficção. Em gesto paradoxal apenas na aparência, é no fingimento da sua configuração que a tessitura artística permite divisar a leitura intima da realidade, para o que lhe ultrapassa, por um lado, mas ao qual ela limita e concede o dom de sua inteligibilidade idiossincrática, porque poética.

0 segundo contributo benjaminiano liga-se ao elemento do sem-expressão. Ele assim delineia o problema: “É o sem-expressão que destrói aquilo que ainda sobrevive em toda aparência bela como herança do caos: a totalidade falsa, enganosa - a totalidade absoluta. Só o sem-expressão consuma a obra que ele despedaça, fazendo dela um fragmento do mundo verdadeiro, torso de um símbolo." (BENJAMIN, 2009, p. 92) A sutileza dialética embala esse trecho. A obra resulta do caos que ela tentou esconjurar ao organizar-se em cosmos. Ao fazê-lo, buscou apagar os traços do processo, pretextando dirimir qualquer dívida que se insinuasse. Mas a linguagem guarda a memória desse apagamento orgulhoso da origem. Trata-se do que Benjamin chama de "o sem-expressão". A oferta legítima de totalidade nutre-se da impossibilidade mesma da obra. Termina-se por encaminhá-la aos fragmentos que margeiam o caos, e assim the doam a porção de verdade que the é devida. Espécie de revelação de uma dívida trágica da 
escrita. Isso é especialmente verdadeiro nos diálogos platônicos. Parece-nos legítima a aproximação dessa sorte de análise com algumas reflexões em torno à figura do instante ${ }^{1}$, exaíphnes, conforme presentes numa passagem clássica do Parmênides (156 d-e) platônico. Ela surge num momento de debate acerca da relação entre movimento e repouso:

pois é óbvio que não se muda a partir do repouso quando se está em repouso, nem se muda a partir do movimento quando se está em movimento. Mas a desconcertante natureza do próprio instante, que reside entre o movimento e o repouso, que não está em nenhum período de tempo, é aquilo para o qual e a partir do qual muda para o repouso aquilo que está em movimento e para o movimento aquilo que está em repouso. (156 d-e)

0 instante, ou o súbito, é caracterizado como algo de "natureza estranha" (phýsis átopós), sem lugar (á-topos). Semelhante peculiaridade the permite funcionar enquanto intermediário (metaxý) entre o movimento e $o$ repouso. Embora o termo não se revista de formulação conceitual, insinua apreço pela temporalidade. Permite entrever algumas pistas para se transcender criticamente os impasses a que o diálogo chegou. Sua função, nesse sentido, é especialmente cara no que tange a favorecer o liame entre o uno e o múltiplo.

Fernando Rey Puente (2010) julga que a figura do tempo em Platão conduziria seja à resistência às interpretações neoplatônicas, seja às nietzschianas. Isso se deveria a que ambas se detiveram exclusivamente nas categorias da transcendência e eternidade na análise da teoria das ideias. 0 reparo feito pelo autor se robustece quando analisa a função exercida por essa figura temporal, 0 instante, no contexto mais amplo da filosofia platônica. Ao referir-se à passagem da alegoria da caverna, quando o prisioneiro é subitamente (exaiphnêes) liberto das suas amarras, Puente observa: "Esse "salto epistemológico" é como que o resultado produzido subitamente depois de longa e paciente frequentação e exercitação." (PUENTE, 2010, p. 53). No caso específico do Parmênides, é precisamente a figura que instrui desconfiança com relação a um suposto dualismo intransigente no pensamento do filósofo grego: “Platão parece estar, na verdade, muito mais interessado nos metaxý do que em uma transcendência radical." (PUENTE, 2010, p. 57). 0 instante enseja assim uma dupla interrupção produtiva: no âmbito do conhecimento, quando permite ao sujeito assestar nível mais avançado de compreensão do mundo; e do liame ontológico entre as Formas e a multiplicidade dos fenômenos.

Monique Dixsaut sustenta ser o foco dessa passagem a busca de se explicar a mudança: "Si donc changer, on ne peut le faire sans changer, quand change-t-on?» (DIXSAUT, 2003, p. 140). Nesse sentido, não conectaria eternidade e tempo, como se sustentou na interpretação neoplatônica do Parmênides. Esse reparo se nos afigura correto. E, no entanto, 0 instante (exaiphnê̂s) ainda assim parece funcionar enquanto figura dessa relação. Avizinha-se da eternidade nesse ponto: em que ambos suspendem o tempo. Diferenciam-se, no entanto, em que o eterno insinua o retorno a si, na unidade do seu recolhimento, das coisas todas infensas ao devir, ao passo que $o$ instante prepara apenas nova rodada de enfrentamento do vir-a-ser na multiplicidade e mergulho nas vicissitudes do tempo. Da segurança (paradoxalmente temporária) do retorno ao eterno à sujeição ao arbítrio do jogo trágico do mundo. ${ }^{2}$

De todo modo, importa sublinhar esse caráter fundamentalmente $a$-tópico do instante: ele não está em tempo algum porque significa precisamente a interrupção do tempo, ensejando então a mudança e o devir: "Le changemente est cet événement pur qui interrompt le cours et la succession du temps qui s'avance" (DIXSAUT, 2003, p. 140). Caberia indagar se a própria tessitura do diálogo platônico, no limiar do silêncio que amiúde o cerca, não suportaria precisamente essa interrupção. Parte do fascínio dessa escrita não residiria nisso - não apenas na temporalidade da inscrição dos debates, mas também do silêncio da sua interrupção recorrente no modo inusitado com que finaliza (amiúde um desfecho sem desfecho) as suas obras?

4. Um estudo sobre a textualidade nos diálogos platônicos pode beneficiar-se de aspectos da investigação hermenêutica de Paul Ricoeur. Em seu ensaio "A função hermenêutica do distanciamento" (2008), objetiva articular dois elementos amiúde
1. Tem sido essa a tradução mais recorrente em português. Mas há quem opte pelo termo "súbito", de modo bastante razoável, como é o caso de Fernando Rey Puente (2010).

2. Tais figuras são recorrentes na poesia lírica moderna. Tome-se, por exemplo, estes versos de Salvatore Quasimodo: "Ognuno sta solo sul cuor della terra / trafitto da un raggio di sole: / ed è súbito sera" (Cada um está só no coração da terra / traspassado por um raio de sol: / e de repente é noite). (QUASIMODO, 1999, p. 18-9). Temos aqui espécie de interrupção que insinua contornos trágicos, em função de um estado de coisas desinteressado do humano, infenso à sensibilidade inteligente (logopoética) da poesia e filosofia. 
vistos como irreconciliáveis: respeitar o núcleo vivo e múltiplo da existência sem que nos escape, pela dispersão e devir, sua significação. Implica assim resistir a uma abstração que nos fornece uma estrutura cognoscivel da realidade, mas descarnada, e uma imersão inocente no devir, a qual, se por um lado nos oferta considerável vitalidade, impõe consideráveis obstáculos à inteligibilidade desses fenômenos.

Coerente com esse projeto, o filósofo apresenta a sua tese: superar a tradicional antinomia entre explicação e compreensão. Semelhante hiato entre os dois procedimentos decorre da luta da hermenêutica, mormente com Wilhelm Dilthey, por colocar os fenômenos humanos ao abrigo da uniformidade causal peculiar aos estudos das ciências da natureza em sua época. Por via em tudo diferente desse tipo de operação científica, calcada na explicação lógico-causal e distanciada dos fenômenos estudados, a compreensão, defendida por Dilthey, seria atitude mais coerente com a especificidade das ciências humanas. Nestas, em vez de separação, encontramos a empatia do sujeito face a um outro que, longe de lhe ser objetivável, surge-lhe também como sujeito a quem se interpreta, mas por meio do qual se é não menos interpretado e interpelado.

Posto que representasse passo importante na salvaguarda da peculiaridade do estudo do humano, semelhante distinção conduziria a impasses e excessos. No caso de Hans-Georg Gadamer a tensão entre as duas operações metodológicas é conduzida à antinomia. Sua obra-prima, Verdade e método, segundo Ricoeur, deveria ter o título modificado para Verdade ou método.

Mas semelhante separação efetivamente corresponderia ao destino da hermenêutica e das ciências humanas? Ricoeur o nega com firmeza. 0s diversos extratos por ele analisados timbram em evidenciar planos diversos de distanciamento que não poderiam ser atribuídos à conduta explicativa das ciências naturais. De algum modo, nas próprias operações do espírito os homens vivenciam o distanciamento. Não se trata agora de algo imposto de fora mediante abstração provinda de metodologia. Precisamente por emergir do próprio jogo de empatia e afastamento é que a articulação entre compreensão e explicação revelam-se não apenas possíveis, mas necessárias (RICOEUR, 2008).

Será mediante a noção de texto que o filósofo apresenta alguns caminhos para a superação da antinomia acima mencionada. 0 texto é o "paradigma do distanciamento na comunicação", da "comunicação na e pela distância" (RICOEUR, 2008, p. 52). 0 passo seguinte será então esclarecer de que critérios de textualidade ele se servirá com vistas a encaminhar o seu estudo. Compõem-se de cinco elementos: "a efetuação da linguagem como discurso", "a efetuação do discurso como obra estruturada", "a relação da fala com a escrita no discurso e nas obras de discurso", "a obra de discurso como projeção de um mundo", "o discurso e a obra de discurso como mediação da compreensão de si" (RICOEUR, 2008, p. 52,) Estes três últimos elementos interessam-nos mais diretamente aqui.

0 texto escrito não se circunscreve às intenções do seu autor. Alcança autonomia, concedendo ao Verfremdung um acento positivo que não tinha em Gadamer (RICOEUR, 2008, p. 62). Além disso, a obra transcende seu contexto psicossociológico, abrindo-se a diversas leituras. Seu movimento vai da descontextualização à recontextualização efetuada pelo ato de ler (RICOEUR, 2008). 0 distanciamento revela-se assim constitutivo da obra, é tanto o que se deve vencer, quanto o que condiciona a interpretação. Numa observação que não deve deixar indiferente os leitores de Platão, o filósofo francês sustenta que decorre desses mecanismos a alteração do funcionamento da referência: “A passagem da fala à escrita afeta o discurso de vários modos; de uma maneira especial, o funcionamento da referência fica alterado quando não nos é mais possivel mostrar a coisa de que falamos como pertencendo à situação comum aos interlocutores do diálogo." (RICOEUR, 2008, p. 63) Mais especificamente, a literatura repõe em outro nível a questão da referência - destruição do mundo para alcançá-lo em sua essência mais íntima. Sua potencialidade crítica reside nisso - abre fissuras mediante as quais se pode ainda pensar. Nesse espaço estético, evidencia-se uma demanda não apenas gnosiológica, mas também ética e política: 
Este é, me parece, o papel da maior parte de nossa literatura: destruir o mundo. Isto é uma verdade da literatura de ficção - conto, mito, romance, teatro -, bem como de toda literatura denominada de poética, onde a literatura parece glorificada em si mesma, em detrimento da função referencial do discurso ordinário." (RICOEUR, 2008, p. 65)

Os resultados dessa investigação acenam para os lugares do leitor. Compreender-se diante da obra torna-se não em um ato de imposição racional, mas de exposição. Em um paradoxo instrutivo, só podemos nos encontrar enquanto leitores, se nos perdemos: "Só me encontro, como leitor, perdendo-me. A leitura me introduz nas variações imaginativas do ego. A metamorfose do mundo, segundo o jogo, também é a metamorfose lúdica do ego." (RICOEUR, 2008, p. 68) Nisso se revela o caráter insuficiente da apropriação enquanto supressão da distância: no mundo da obra distanciamo-nos de nós mesmos.

0 estudo da argumentação platônica, tal como realizado por Franco Trabattoni, parece fortalecer semelhante linha investigativa. Haveria no filósofo grego uma precoce consciência hermenêutica da linguagem, mormente da falta de fundo da linguagem e do pensamento: “Nisso, manifesta-se, de fato, uma característica estrutural e não eliminável do pensamento e da linguagem, ou seja, sua infinita declinabilidade, sua substancial falta de fundo." (TRABATTONI, 2010a, p. 17) Este movimento teria sido silenciado por Aristóteles, sendo responsável por ocultar-se instância fecunda de pesquisa acerca dos diálogos, conforme sustenta o autor em um momento provocativo (TRABATTONI, 2010a). Nesse fluxo infinito de possibilidades na linguagem, os diálogos platônicos fiam estrategicamente 0 movimento circular e intérmino do pensamento. Divisa-se o quadro de um filósofo em tudo infenso ao dogmatismo, tornando uma após outra injustificadas as crítica movidas contra ele por setores do assim chamado pensamento pós-moderno. Não se pode negar ousadia à tese de Trabattoni.

Resulta disso o necessário cuidado com a materialidade da escrita platônica, sublinhando seus substratos hermenêuticos, vazados em precariedade, como é afim ao próprio ato de escrever. A retórica, longe de ser o avesso do logos, pode ser mesmo o meio em que se dissemina o drama do conhecimento. Os diálogos seriam um modo de representar a não-exaustividade do mundo em que o homem vive, o que o autor chama de "vicariedade". Este é precisamente, segundo lhe parece, o sentido da teoria das ideias. A reminiscência platônica configura o assesto dessa errância intérmina do pensar:

Essa situação é expressa por Platão por meio da metáfora (mesmo que, talvez, não se trate só de uma metáfora) da doutrina da reminiscência, segundo a qual conhecer é recordar: um recordar que, evidentemente, se desenvolve por rastros, lampejos e resíduos, logo não pode mais reunir o estado de exaustividade a que uma definição gostaria de aspirar. (TRABATTONI, 2010a, p. 14-5)

Nesse fluxo de questões e indagações, a filosofia vai delineando suas vias mais férteis de aprimoramento e progresso. Mas não se faz justiça a Platão se, ao resistirmos às acusações extremadas de dogmatismo, o encaminhamos a um puro jogo cético ou à complacência relativista. Pois isto é exatamente o que os diálogos não fazem. Atento a esses riscos, Trabattoni esclarece ser peculiar ao platonismo o compromisso com a articulação entre unidade e multiplicidade: "a unidade do múltiplo" (2010a, p. 22) A pergunta socrática, nesse sentido, se faz não para alcançar a verdade absoluta, e sim colocar em cena o universal: “põe em evidência o terreno do universal em que move o logos" (2010a, p. 23). A voragem desconstrutivista em sua obsessão pela diferença apenas se faria inteligível se articulada ao platonismo, esse pretenso outro sobre o qual lançou reptos os mais diversos. Não obstante, a defesa de semelhante articulação da unidade e multiplicidade não implica afirmar que sua posse seja algo pacífico, fácil. Evidencia-se, de outro modo, justamente a precariedade da busca.

A argumentação platônica, seu artesanato textual resiste, de um só golpe, ao dogmatismo e ao ceticismo ${ }^{3}$. Tais são as condições essenciais à construção de um diálogo, ou ao menos para a expectativa de sua possibilidade. 0 élan dessa aproximação na distância franqueada (ou, ao menos, desejada) pelo
3. Em importante pesquisa acerca do tema da política na filosofia platônica, Mario Vegetti subli-nhou um elemento de interesse para a presente discussão: a defesa da polissemia do texto platônico: "Esforços hermenêuticos orientados podem, diria, devem ser levados a cabo, porque um excesso de tolerância acarreta um pressuposto de irrelevância teórica da interpretação, mas é igualmente verdade que estes esforços devem por outro lado, aceitar uma margem irredutível de polissemia do seu objeto: o pensar filosófico de Platão - pela mesma forma textual em que é representado - não pode ser reduzido a um sistema unívoco de significados." (VEGETTI, 2010, p. 272-3) 
diálogo vive da expectativa de um encontro genuíno, sob o signo, embora ainda impreciso, da verdade. Se alguém tem a verdade, suspende o tempo, e nos dita o caminho a seguir; se a sua aproximação é impossível, a conversa torna-se em um jogo vão. Tais as exigências do diálogo, em particular, e da filosofia, em geral. Deve-se a Platão a mais ousada convergência entre as duas instâncias.

5. Numa mostra de que ao se elaborar uma hipótese, o rigor pode pagar tributo à beleza, Jeanne Marie Gagnebin sustenta que, tal como Homero, no exercício de oferecer glória eterna aos seus heróis, Platão também teceria quadros similares em seus diálogos: monumento à memória de Sócrates. Trata-se de uma reminiscência que se afirma na precariedade da palavra poética:

o impulso para filosofia em Platão - em particular para escrever diálogos filosóficos, apesar de suas numerosas críticas à escrita -, provém não só de uma "busca da verdade", meio abstrata, mas também da necessidade, ligada a essa busca, de defender a memória, a honra, a glória, o kléos do herói/mestre morto, Sócrates. (GAGNEBIN, 2006b, p. 196)

Essa hipótese busca fortalecer-se mediante análise de alguns diálogos, sobretudo a Apologia. Quando Sócrates reflete acerca da sua escolha de uma vida dedicada à verdade, ainda que sob riscos os mais diversos, insere-se no interior de um quadro afirmativo da sua heroicidade peculiar: “Nesse contexto, podemos também dizer que Platão assume, em relação ao mestre morto, a mesma função que cabia ao poeta em relação aos heróis mortos: lembrar suas façanhas e suas palavras para que a posteridade não se esqueça dos seus nomes e de sua glória." (GAGNEBIN, 2006b, p. 196) Semelhante projeto exigirá do filósofo grego apuro na textualidade dos diálogos, os quais timbram no esforço de conceder aquela "imagem exemplar" de Sócrates. A ficção, nesse sentido, não seria o avesso da verdade, mas a sua persecução por outras vias: “Todos os estudiosos de Platão que analisam, por exemplo, as encenações iniciais dos diálogos, sabem dessas construções complexas (para não dizer... sofisticadas!)." (GAGNEBIN, 2006b, p. 198)
Revela interesse, nesse cenário, os motivos da ausência do autor enquanto sujeito do enunciado dos diálogos. Segundo Gagnebin, tal se justifica pela busca de garantir a objetividade (GAGNEBIN, 2006b, p. 198-9). A resposta é, em linhas gerais, correta. Mas resulta insuficiente. Parece-nos que, além disso, Platão se ausenta para que o drama possa emergir, assim garantindo força à exibição da cena - de que resulta, também, a precariedade e temporalidade do escrito.

Mas Platão se ausenta de todo? É este o seu intento? Trata-se de fazer funcionar o drama por ele escolhido. A ficção fortalece a verdade. Ao mesmo tempo, pelo misto de estabilidade e precariedade da escrita, encena em si o caráter vivo e arriscado dessa busca. A heroicidade decantada nos poemas homéricos tem seu correlato perfeito na própria armadura dos diálogos, sendo seu objeto a vida de Sócrates. Ainda sobre a "morte exemplar" de Sócrates construída nos diálogos, algumas considerações. Parece-nos que o conjunto formado pela Apologia, o Críton e o Fédon fornecem indícios de um procedimento ousado da escrita platônica: elabora metáforas de morte, e a morte como metáfora, gesto constitutivo da cultura humana, a que a escrita platônica concedeu uma forma inesquecivel.

6. Aristide Valentin é um personagem de histórias policiais criado por G. K. Chesterton. Num momento melancólico, quando compara sua obra à dos criminosos que persegue, ele observa para si mesmo: "The criminal is the creative artist; the detective only the critic" (CHESTERTON, 2003, p. 15) 0 crítico e o leitor em busca dos traços e pistas deixados pelo texto - o criminoso enquanto imagem da transgressão, e o detetive enquanto hermeneuta da transgressão, e ao mesmo tempo, o que recupera a ordem, expressa na temporalidade da leitura. Trata-se, para nos servirmos do belo título de Martha Nussbaum, da "fragilidade da leitura".

Hans Robert Jauss escreveu um texto numa direção semelhante sobre o prazer estético em 1977, intitulado "0 prazer estético e as experiências fundamentais da poiesis, aisthesis e katharsis" (JAUSS, 2011). Inicialmente, faz um retrospecto dos principais teóricos que trataram do tema, fazendo-os dia- 
logar entre si e, em seguida, apresenta a sua própria perspectiva. É nesta parte que nos concentraremos.

A ação humana na atividade estética move-se sob três funções: poiesis, aisthesis e katharsis. A primeira liga-se à "obra que nós mesmos realizamos" (JAUSS, 2011, p. 100). A aisthesis, por sua vez, configura a recepção prazerosa, a visão renovada e intensificada. Com relação à katharsis, refere-se à transformação liberadora do automatismo do cotidiano: "Designa-se por katharsis, unindo-se a determinação de Górgias com a de Aristóteles, aquele prazer dos afetos provocados pelo discurso ou pela poesia, capaz de conduzir o ouvinte e o espectador tanto à transformação de suas convicções quanto à liberação de sua psique." (JAUSS, 2011, p. 101) Essas três funções acham-se num intercâmbio dinâmico, sobrepondo-se e relacionando-se entre si. Um bom exemplo, o qual inclusive aponta para liames intertextuais, dá-nos o autor quando sublinha o momento em que a aisthesis se tornaria em poiesis, quando o leitor, ao perceber a suposta incompletude do objeto estético, pode "sair de sua atitude contemplativa e converter-se em co-criador da obra, à medida que conclui a concretização de sua forma e de seu significado." (JAUSS, 2011, p. 103)

0 texto encerra-se com uma citação luminosa de Goethe: "Há três classes de leitores: o primeiro, o que goza sem julgamento, o terceiro, o que julga sem gozar, o intermédio, que julga gozando e goza julgando, é o que propriamente recria a obra de arte." (JAUSS, 2011, p. 103) 0 ato de ler reveste-se assim de notável complexidade. Longe de ser mera decodificação de textos, assume os riscos da participação criativa no processo estético. E é sob a experiência do prazer estético que a dicotomia do gozo e do julgamento tem possibilidades mais consistentes de ser superada. A leitura perde a inocência, mas reivindica agora o direito à criação. Não se contenta com ser o duplo inferior do mundo dos textos. Pretende então interpelá-los e recriá-los sob o signo das exigências mais altas da sua própria época.

E são precisamente altas as exigências feitas pela escrita platônica. Seu caráter dramático, afim ao teatro, demanda inserção ativa dos leitores, semelhante, como nota Martha Nussbaum, aos mo- vimentos do espectador na tragédia: "Assim como ao espectador de uma tragédia, a interação solicita ao leitor do diálogo que elabore tudo ativamente e que veja onde ele realmente se posiciona, quem é realmente digno de louvor e por quê." (NUSSBAUM, 2009, p. 112) ${ }^{4}$ A forma-diálogo, conforme esclarece a autora, incita ao julgamento crítico. Não apenas representa a cena dos seus interlocutores, mas também a cena virtual da intervenção dos leitores. A nosso ver, o silêncio da leitura é afim ao "diálogo íntimo da alma consigo mesma, que nasce sem voz" (Sofista, 263e).

Segundo Nussbaum, no entanto, a comparação com a tragédia não deve nos fazer descurar as muitas diferenças entre os gêneros. Sobretudo pelo seu efeito, uma vez que a escrita platônica seria movimentada pelo apelo ao intelecto. Mesmo os mitos enfeixam-se num intuito filosófico conducente a uma abstração progressiva: “Ele o emprega não para que por si mesmo entretenha, mas para manifestar verdades filosóficas gerais em cujo favor já argumentou" (NUSSBAUM, 2009, p. 116) Mas parece faltar a esse estudo considerações sobre a imaginação nesses mitos, sobretudo em seu teor metafórico. Ricoeur assim concebe 0 ato de imaginar: "imaginar é fazer-se ausente no todo das coisas." (RICOEUR, 1992, p. 155) 0 recorte do filósofo francês é fenomenológico. Seu impulso, não obstante, quadra-se com as aspirações elevadas da filosofia platônica, cuja escrita, em sua materialidade, impele a uma purificação do trato com a lide cotidiana dos objetos com vistas a alcançá-los, paradoxalmente em sua ausência, a nível mais profundo de compreensão. Imaginar e pensar implicam-se mutuamente, e exibem-se na cena sedutora da linguagem platônica.

Neste contexto algumas passagens do Banquete nos podem ser elucidativas. 0 diálogo abre com a representação do plano da reminiscência que se desdobra ao longo da obra. Nessas narrativas múltiplas, uma dentro da outra, tal como as estátuas dos sátiros referidas a Sócrates, divisamos a arte de um ficcionista. Aristodemo havia contado a estória do que testemunhara a Apolodoro, e este aos seus ouvintes no diálogo: “ $E$, se vocês me requerem para fazer essa narrativa, é mesmo dever meu fazê-la." (173c) Não apenas ao Companheiro, mas também
4. Comparar com uma interpretação semelhante de Trabattoni: "na falta de uma situação mais adequada, ou seja, quando é possível chegar ao interlocutor somente por meio do texto es-crito, o melhor modo de se aproximar do colóquio oral é o diálogo. 0 diálogo compromete, antes de tudo, Sócrates e os outros protagonistas das conversações platônicas; mas envolve ativamente também 0 leitor, que, a partir do texto assim construído, obtém estímulos para a investigação pessoal com muito maior eficácia do que as que poderia extrair da exposição de uma doutrina." (2010b) 
aos leitores. Nos rastros da reminiscência, insinua-se a força e a fragilidade do drama do conhecimento platônico. Apolodoro, logo no início, confessa:

Com respeito aos discursos que cada um fez, é claro que Aristodemo não reteve todos os pormenores, como também eu não retive tudo aquilo que ele me contou. (177e)

Ressalta-se, por essa via, o caráter produtivo da memória - e o da leitura. Numa passagem vazada em picardia, Guimarães Rosa afirmou: “0 livro pode valer pelo muito que nele não deveu caber." (1994, p. 526) Nos interstícios do Banquete, no nível da reminiscência, reside uma aposta de sedução: que os leitores aceitem o convite do gozo e do pensamento. A julgar pela nota rosiana, o valor dessa obra depende de semelhante intervenção.

Acima nos referíamos à figuras da interrupção em Platão. As reviravoltas cômicas do Banquete são bastante sugestivas nesse sentido. Primeiramente, 0 atraso de Sócrates, imerso em seus pensamentos (174d-175c). Um pouco adiante, antes que pudesse discursar, Aristófanes é vítima de um ataque de soluços (185d-e). Ambas essas cenas despertam o riso, ainda que discreto, um riso afim ao gozo da identidade do espírito consigo mesmo a partir das contradições de um evento. Gesto infenso à reverência, preparatório, assim, da filosofia. Há também outras duas interrupções, quando da chegada de Alcibíades (212c-d), e da entrada dos foliões (223b). Quebram certa expectativa de ordem, fazendo assim mover-se teatralmente o texto. Não lhe basta a argumentação cerrada - é também necessário agradar, despertar prazer.

Inscreve-se em gesto similar a construção da imagem do sofista no Sofista, movida por arte de grande elaboração e mordacidade, mediante definições com as quais a dialética paga tributo à ironia e ao humor. Tomemos como exemplos algumas delas. Na primeira, ele é apresentado com propriedades de um caçador, que se distingue no gênero por visar, como presa, jovens ricos: “Outro, vai à terra e a rios diferentes - de riqueza e juventude -, como em prados copiosos capturar as criaturas desses lugares." (222a). A segunda caracterização liga-se à arte do comerciante: o sofista importa conhecimento (mathematopoliké) e virtude (224c). Não lida com o saber, mas com a sua aparência, pois lhe interessa tão somente o lucro e a ostentação: “Então, o sofista revela-se-nos tendo um certo saber sobre a arte da opinião acerca de tudo, mas não um saber verdadeiro" (233c), observa o Estrangeiro em diálogo com Teeteto. 0 sofista oferece assim dóxa, e não epistéme.

Outra peça nessa representação, recorrente na obra platônica e aqui articulada a dupla voz, combina sofística e imitação. Suas palavras eivadas de logro simulam uma realidade da qual, efetivamente, configuram apenas uma duplicação distorcida (234d). Se alguém propugna pelo dualismo, na prática, seria o sofista, não Platão. É o sofista quem por meio de simulacros (phántasma) produz o duplo fraudulento do mundo. Por esse razão situa-se "como um ilusionista e um imitador" (235a).

Haveríamos, no entanto, de reenviar ao questionamento platônico a suspeita de que a construção da imagem do sofista se faz por via igualmente mimética. Ao se refutar a legitimidade filosófica e pedagógica do trabalho desses homens por fundar-se na imitação, Platão o faz mediante recursos eles mesmos miméticos. Bem se poderia objetar que esse exercício não produz simulacros, mas a imagem efetiva desses pensadores. Se é assim, existiria uma arte mimética legítima - que emerge não exatamente do conteúdo dos debates, mas da forma mesma do diálogo. De qualquer modo, a tensão (dramática?) parece instalar-se.

7. Não são muitos os filósofos que, tal como Platão, concedem tamanha importância ao efeito de uma obra artística sobre o público. Ao sublinhar os riscos a que nos expomos na vizinhança da arte, toma muito a sério a força expressiva da poesia, mormente a trágica. Trata-se da notável ambiguidade de um cuidado que ao buscar nos acautelar dos perigos de algo, desperta precisamente o interesse nesse tipo de experiência. Além disso, permite entrever fissuras no projeto antropológico estribado no controle da chamada parte superior da alma - superior não raro submetida aos caprichos da parte inferior. 
Algo semelhante nota-se nessa passagem do Crátilo, que surpreende ao admitir a força irresistível do desejo: "Sócrates - Vou dizer-te o que me parece. Diz-me o seguinte: dos laços que mantêm qualquer ser vivo seja onde for, qual é o mais forte, a necessidade ou o desejo? Hermógenes - É o desejo, ó Sócrates, e de muito longe." (403c). Tal preocupação é recorrente em algumas passagens da República, especialmente nos livros III e X. Há naquele uma advertência contra as fábulas, pois algumas arrefecem a coragem - inibem o desenvolvimento das virtudes:

Por conseguinte, temos, parece-me, de exercer vigilância também sobre os que tentam narrar estas fábulas e de lhes pedir que não caluniem assim sem mais o que respeita ao Hades, mas que antes o louvem, quando não as suas histórias não são verídicas nem úteis aos que se destinam ao combate. (386 b-c).

Outrossim, o filósofo expressa a desconfiança com relação ao efeito de enfeitiçamento do discurso poético: “quanto mais poético, menos devem ser ouvidos por crianças e por homens que devem ser livres." (387b) Lamentações pelos mortos convém igualmente que sejam evitadas, pois podem fazer emergir temor excessivo pela morte.

É recorrente no texto o intento de investigar os meios com que se fortaleceria a temperança (sophosýne) e o domínio de si, passos não raro negligenciados, segundo Platão, pelos poemas homéricos. Mas essas críticas por vezes se fazem acompanhar por hesitações referentes à excelência do poeta: "Hesito (...) por consideração por Homero" (391a) Coerente com os seus pressupostos metafísicos e pedagógicos, dedica-se a uma revisão crítica do conceito de deus e herói, sobretudo no que tange à questão dos seus atributos: "é impossível que o mal venha dos deuses" (391e) Um herói tal qual Aquiles, por exemplo, não poderia ser ambicioso, tampouco nutrir desprezo pelos homens e pelos deuses. Era este o problema dos antigos atributos: "cada um arranjará desculpa para a sua maldade" (391e).

É manifesta a cautela com relação ao riso violento, motivada por considerações éticas: “Mas, na verdade, também não devem ser amigos de rir; porquanto quase sempre que alguém se entrega a um riso violento, tal facto causa-lhe uma mudança também violenta." (388e) A dificuldade do passo pode aferir-se se a comparamos com o uso da ironia e do humor em diversas passagens da obra platônica. Tome-se, por exemplo, a seção do Sofista na qual Sócrates cuida da delimitação do ofício dos sofistas (222a-231e). 0 quadro timbra pela boa disposição da cena na qual, pelo ridículo e o riso, se desdobra o passo claudicante dos sofistas. Não chega a ser uma contradição, mas uma amostra do cuidado do filósofo no tratamento de alguns temas, respeitandothe a complexidade. De qualquer modo, a assimetria entre o plano do conteúdo filosófico e a produção artístico-formal dos diálogos é por demais sugestiva para que não suscite a necessária atenção - e certa desconfiança.

Chega-se então ao estudo da imitação (mímesis), mediante a qual se procede a uma primeira distinção entre os gêneros literários. Investiga-se a peculiaridade da epopeia e da tragédia e comédia. Na primeira combinam-se forma narrativa e dramática, nas outras duas, forma dramática, que é, para o filósofo, tessitura imitativa por excelência (395a). A imitação, diferentemente da narrativa, define-se por alguém fazer passar-se, de algum modo, por outrem: “Mas, quando ele [o poeta] profere um discurso como se fosse outra pessoa, acaso não diremos que ele assemelha o mais possivel o seu estilo ao da pessoa cuja fala anunciou?" (393c). No livro III aceita-se a poesia de caráter narrativo. Semelhante acolhimento desaparece no livro $X$, por ocasião da célebre invectiva contra os poetas. Trata-se agora da fundação da cidade ideal e do estatuto da poesia no que tange à política e à educação. Ao deter-se criticamente sobre o objeto, emerge não apenas uma suposta animosidade; também suscita a suspeita de que o filósofo, nesse trabalho esmerado, finda por conceder justamente importância à poesia. Recusa-se por essa via a poesia de caráter mimético: “não aceitar a parte da poesia de carácter mimético. A necessidade de a recusar em absoluto é agora, segundo me parece, ainda mais claramente evidente, desde que definimos em separado cada uma das partes da alma." (595a)

A primeira crítica dirige-se ao fato de que as 
5. Lembremo-nos do célebre poema "Psicografia", de Fernando Pessoa: "0 poeta é um fingidor". obras miméticas desviam-nos do conhecimento da verdade: "todas as obras dessa espécie se me afiguram ser a destruição da inteligência dos ouvintes, de quantos não tiverem como antídoto o conhecimento da sua verdadeira natureza" (595b). Além disso, afastam-nos em três graus da verdade. Os poetas imitam as obras dos artífices os quais, por sua vez, imitam o artífice natural, Deus. Trata-se, destarte, de imitação da aparência, e não da realidade, conforme 0 exemplo das três camas. Nesse contexto, Platão apresenta a hipótese de que a tragédia teria o seu nascedouro em Homero. Uma hipótese percuciente, que poderia advir tão somente de quem conhecesse a tragédia com intimidade. Que seja articulada por seu crítico contumaz é notável peça de ironia: "a tragédia e o seu corifeu, Homero" (598d). Um pouco adiante, vê Homero como "o primeiro dos tragediógrafos" (607a) Não apenas nessa passagem, mas em todo o livro $X$ o filósofo grego, na avaliação implacável que faz da poesia em geral e, sobretudo, da tragédia, demonstra tamanho conhecimento dos meandros dessa arte que se arrisca amiúde a convencer-nos precisamente do oposto do que tenciona, ou seja, da relevância incomensurável da poesia, da infungibilidade dos seus signos.

Também problemático é o fato de os poetas não saberem o que é a virtude: “- Assentemos, portanto, que, a principiar em Homero, todos os poetas são imitadores da imagem da virtude e dos restantes assuntos sobres os quais compõem, mas não atingem a verdade" (600e) Não sabendo o que ela é, não podem obrar em conformidade com as suas exigências, e mesmo quando por vezes logram fazê-lo, não o é de modo consistente.

Platão, não raro, quanto mais nega a poesia, mais se acerca da sua essência, e precisamente da afirmação da sua relevância. É o que se observa quando a relaciona a um jogo e afirma que ela conduz ao arrebatamento, ao extravio: “o imitador não tem conhecimento que valham nada sobre aquilo que imita, mas que a imitação é uma brincadeira sem seriedade." (602b) Uma observação a que não falta acuidade. Entretanto, está longe de fundar razões bastantes para o abandono dessa atividade. Ao invés, em seu jogo ela movimenta itinerário afim á própria filosofia: resiste a demandas utilitárias, estribando- -se tão somente na faculdade livre da sua expressão. A contrapelo do que intentava, o filósofo grego abre via fértil de investigação cujo arremate será uma consistente apologia da criatividade artística em autores os mais diversos, entre os quais se pode mencionar Johan Huizinga e Hans-Georg Gadamer. A arte é um jogo. Não o seria também a filosofia?

A crítica ao arrebatamento que a poesia enseja emerge de um trecho dedicado ao elogio da calma, por seu acordo à lei e à identidade: “o carácter sensato e calmo, sempre igual a si mesmo" (604e) É uma qualidade bela e difícil de imitar. Algo diversa é a ação do poeta. Ele finge sofrimentos de que não padece: “Porquanto essa imitação seria de um sofrimento que, para eles, é estranho." (604e). Ao resistir-se à calma, produz-se no sujeito diferença radical consigo mesmo. Sentimentos contraditórios desviam-no do eixo (a razão).

Toda essa crítica ao caráter mimético da poesia tem em sua expulsão da cidade ideal seu arremate lógico (607a). Convém agora, atendendo a preceitos filosóficos, que se ocupem os homens com temas e tonalidades capazes de fomentar a temperança e o respeito aos deuses. Focalizam-se agora valores conducentes ao cuidado com a imortalidade da alma (608e). É nesse tempo e espaço que se introduz a história de Er. Belo desfecho: após a expulsão da poesia, o filósofo grego desfia raro talento na construção de uma prosa marcada precisamente pela forma e imaginação poética.

Essas hesitações platônicas foram bem examinadas por um estudioso contemporâneo (RUTHERFORD, 1995). São de dois tipos. 1. As asserções presentes na República não se fazem sem a necessária reconsideração da consistência das suas afirmações. 0 receio de se proceder à desmedida confiança, à hybris no âmbito do conhecimento, faz-se acompanhar por uma meditação temperante. Misto de prudência e zelo socrático. No livro VII, no âmbito das discussões sobre o bem em si, lemos: "tende cuidado em que não vos engane sem querer" (507a). Dúvidas com respeito à imagem em palavras oferecida por Sócrates a Gláucon expressam-se um pouco adiante, também no livro VII (533a). Rutherford observa: "We may suppose that Plato is concerned to preserve, even in the vast exposition of 
the Republic, the original modesty and admissions of ignorance which were surely typical of Socrates; yet the preoccupation with the limits and imperfections of his methods and words seems to go deeper still." Logo a seguir arremata: "It seems that the exposition in the Republic is partial and tentative; the gap between what Socrates has achieved and what the poets can do is not so vast as we at first anticipated." (RUTHERFORD, 1995, p. 235) 2. Por outro lado, a magia insubmissa da poesia não é menos encontradiça na filosofia. Nela também a sedução da escrita literária insinua-se pelos diálogos: "Plato is the greatest critic of Homer and tragedy; but he also learns from them and seeks to rival them. To put it in another way, Plato uses the arts of literature in the service of philosophy" (RUTHERFORD, 1995, p. 237). Em que pese o caráter questionável dessa função instrumental da arte literária, o comentário tem o mérito de sublinhar as margens de hesitação constantes da reflexão platônica. Mesmo a arte da dialética, com sua sofisticada racionalidade, demanda a ação criativa dos seus atores (DIXSAUT, 2003, p. 168)

A essas flutuações e desvios da escrita pode-se encaminhar uma preocupação. A exaltada defesa da filosofia deixa a impressão de uma lacuna essencial: um déficit na lide simbólica com o mundo decorrente do abandono da poesia. Tema de interesse pedagógico de primeira ordem, cujo exame não se deveria ausentar numa reflexão filosófica acerca do estatuto de uma cidade ideal. Que isso se faça em texto movido não raro por cerrada cifra poética, demonstra a complexidade da questão, no empenho por expressar em configuração dramática a busca do conhecimento.

Tais hesitações, se não fazem de Platão um autor trágico, podem ao menos matizar os planos de superioridade do discurso filosófico com respeito à tragédia. Não se pode garantir conhecimento sem percalços desse nível em que se processam os dilemas e instabilidade humanos. Se encena 0 fracasso na perseguição do ideal, não sustenta, necessariamente, o abandono do Ideal - tão somente a exibição da cicatriz da busca. Assim como o seu mestre, não raro o escritor Platão apenas sabe do que desconhece.

\section{Referências bibliográficas}

BAILLY, A. (2000). Le grand Bailly - dictionnaire grecfrançais. Paris, Hachette.

BENJAMIN, W. (2009). As afinidades eletivas de Goethe. In: Ensaios reunidos: escritos sobre Goethe. Tradução Mônica Krausz Bornebusc, Irene Aron e Sidney Camargo. São Paulo, Ed. 34.

CHESTERTON, G. K. (2003) The blue cross. In: Father Brown: selected stories. London, Collector's Library.

DIXSAUT, M. (2003) Platon: le désir de comprendre. Paris, J. Vrin, 2003.

GAGNEBIN, J. M. (2006a) As formas literárias da filosofia. In: .Lembrar escrever esquecer. São Paulo, Ed. 34.

(2006b) Platão, creio, estava doente. In: - Lembrar escrever esquecer. São Paulo,

Ed. 34.

JAUSS, H. R. (2011). 0 prazer estético e as experiências fundamentais da poiesis, aisthesis e katharsis. In: LIMA, L. C. (Org.) A literatura e o leitor: textos de estética da recepção. Tradução de Luiz Costa Lima. 2. ed. Rio de Janeiro, Paz e Terra.

NUNES, B. (1993) No tempo do niilismo. São Paulo, Ática.

NUSSBAUM, M. (2009) A fragilidade da bondade: fortuna e ética na tragédia e na filosofia grega. Tradução de Ana Aguiar Cotrim. São Paulo, Martins Fontes.

PLATÃo (2010). O Banquete. Tradução Maria Teresa Schiappa de Azevedo. Lisboa, Edições 70.

(2001) Crátilo. Trad. Maria José Figueiredo. Lisboa, Instituto Piaget.

(1990) República. Tradução e notas Maria Helena da Rocha Pereira. 6. ed. Lisboa, Calouste Gulbenkian.

(2011) Sofista. Tradução Henrique Murachco, Juvino Maria Jr. e José Trindade Santos. Lisboa, Calouste Gulbenkian.

PLATON. (2011) Oeuvres completes. Organisation de Luc Brisson. Traduction de Luc Brisson et. al. Paris, Flammarion.

PUENTE, F. R. (2010). 0 súbito (exaíphnes) em Platão. In: Ensaios sobre o tempo na filosofia antiga. São Paulo, Annablume.

RICOEUR, P. (2008) Interpretação e ideologias. Organização e tradução de Hilton Japiassu. Petrópolis, Vozes.

. (1992) 0 processo metafórico como cognição, imaginação e sentimento. In: SACKS, S. (org.) Da metáfora. Tradução de Leila Cristina M. Darin et al. São Paulo, EDUC/ Pontes, 1992.

ROSA, G. (1994) Fiç̧ão completa. Rio de Janeiro, Nova Aguilar. $2 \mathrm{v}$

RUTHERFORD, R. B. (1995) The art of Plato - ten essays in Platonic interpretation. Cambridge, Harvard University Press. 
TRABATTONI, F. (2010a). A argumentação platônica. ARCHAI: Revista de Estudos sobre as Origens do Pensamento Ocidental. Brasília, n. 4, p. 11-27, jan.

(2010b) Platão. Tradução de Rineu Quinalia. São Paulo, Annablume. (Coleção Archai: as origens do pensamento ocidental, 2).

VEGETTI, M. (2010) Um paradigma no céu: Platão político, de Aristóteles ao século XX. Tradução de Maria da Graça Gomes de Pina. São Paulo, Annablume, 2010. (Coleção Archai: as origens do pensamento ocidental, 4)

Recebido em novembro de 2012 e aprovado em fevereiro de 2013. 